\title{
Evaluation of Physicochemical and Biological Stability of 36-Months-Aged SB5 (Adalimumab Biosimilar) for 4 Weeks at Room Temperature
}

\author{
Dongkuk Park · Jihoon Yun · Su-Jeong Hwang · Su Jin Park
}

Received: October 31, 2018 / Published online: December 15, 2018

(C) The Author(s) 2018

\begin{abstract}
Introduction: Tumor necrosis factor (TNF-alpha) inhibitors, such as adalimumab, have shown success in treating autoimmune inflammatory diseases but are associated with substantial financial burdens to the healthcare system. Biosimilars, which are highly similar to biologic agents, offer the potential to reduce the financial burden of treatment. In the case of TNF-alpha inhibitors, they may also offer improved stability and enable prolonged use. SB5, an adalimumab biosimilar, has shown equivalent efficacy and comparable safety to its reference product in clinical trials. Currently, SB5 is approved for storage for 36 months at $2-8{ }^{\circ} \mathrm{C}$ and may be stored at room temperature $\left(25^{\circ} \mathrm{C}\right)$ for a maximum period of 14 days. The objective of this study was to evaluate the stability of SB5, aged to its shelf-life of 36 months, at room temperature $\left(25 \pm 2{ }^{\circ} \mathrm{C}\right)$ and $60 \pm 5 \%$ relative humidity ( $\mathrm{RH})$ for a period of 4 weeks, which is longer by 14 days than that of SB5 currently approved in the European Union.
\end{abstract}

Enhanced Digital Features To view enhanced digital features for this article go to https://doi.org/10.6084/ m9.figshare.7380683.

D. Park · J. Yun · S.-J. Hwang · S. J. Park $(\varangle)$

Analytical Method Development Team, Samsung

Bioepis Co., Ltd., Incheon, South Korea

e-mail: sujin8171.park@samsung.com
Methods: This study evaluated the stability of SB5, aged to its shelf-life of 36 months, at room temperature $\left(25 \pm 2{ }^{\circ} \mathrm{C}\right)$ for a period of 4 weeks. Three independent batches of 36 months-aged SB5 were stored at $25 \pm 2{ }^{\circ} \mathrm{C}$ and $60 \pm 5 \% \mathrm{RH}$ for 4 weeks. Samples were tested at 0,2 , and 4 weeks.

Results: Color, clarity, visible particles, $\mathrm{pH}$, protein concentration, and particulate matter were consistent among the batches, and all the test results met the acceptance criteria at each time point. Percent charge variance was maintained over time. Percent of high molecular weight species detected, total purity, relative binding activity by TNF-alpha, and relative potency by TNF-alpha neutralization did not change over time within each batch, and all values were within the acceptance criteria limits.

Conclusion: SB5 aged for 36 months is physicochemically and biologically stable for 4 weeks at $25 \pm 2{ }^{\circ} \mathrm{C}$ and $60 \pm 5 \% \mathrm{RH}$, which is 2 weeks longer than the alternative storage condition as approved by the European Medicines Agency, which is at $25^{\circ} \mathrm{C}$ for a period of up to 14 days.

Funding: Samsung Bioepis Co., Ltd.

Keywords: Adalimumab; Biosimilar; Humira; Imraldi; Rheumatology; Room-temperature stability; SB5; Storage 


\section{INTRODUCTION}

Adalimumab (reference product: Humira ${ }^{\circledR}$; AbbVie Deutschland GmbH \& Co. KG, Ludwigshafen, Germany), a recombinant IgG1 monoclonal antibody that selectively blocks the activity of human tumor necrosis factor (TNF-alpha), is approved for the treatment of several diseases including rheumatoid, juvenile idiopathic, and psoriatic arthritis, ankylosing spondylitis, Crohn's disease, ulcerative colitis, plaque psoriasis, and hidradenitis suppurativa [1]. Adalimumab specifically binds TNF-alpha to inhibit its interaction with cell surface receptors [1] and to reduce inflammatory and autoimmune responses [2, 3]. Biosimilars, which are highly similar to biological originators, are being developed to help decrease costs associated with the use of reference products [4]. SB5 (Imraldi ${ }^{\circledR}$; Samsung Bioepis NL, Delft, The Netherlands) has an identical amino acid sequence as well as similar physicochemical and in vitro functional properties as the reference adalimumab (ADA) [5, 6]. A phase I study compared the pharmacokinetics (PK) of SB5 with ADA (European Union- and United States-sourced) and found similar PK profiles for all three compounds in healthy subjects [7]. Furthermore, results from a phase III, randomized, double-blind study reported equivalent efficacy and comparable safety between SB5 and ADA in patients with rheumatoid arthritis [8].

Adalimumab and the ADA biosimilars, Amgevita $^{\mathrm{TM}}$ (Amgen Europe, Breda, The Netherlands), Hyrimoz ${ }^{\circledR}$ (Sandoz GmbH, Kundl, Austria), $\quad$ Cyltezo $^{\circledR} \quad$ (Boehringer Ingelheim International $\mathrm{GmbH}$, Ingelheim am Rhein, Germany), and Hulio ${ }^{\circledR}$ (Mylan S.A.S., Saint-Priest, France) have been approved to be stored for 24 months at $2-8{ }^{\circ} \mathrm{C}[1,9-12]$. In circumstances where refrigeration is not available, these products may be stored at room temperature $\left(25^{\circ} \mathrm{C}\right)$, with protection from light, for $\leq 14$ days [1, 9-12]. These storage limitations may potentially pose inconvenience for patients who may face extended periods without continuous access to refrigeration. As such, there is a perceived need for longer storage at room temperature $\left(25^{\circ} \mathrm{C}\right)$.

Currently, SB5 is approved for storage for 36 months at $2-8{ }^{\circ} \mathrm{C}$ and may be stored at room temperature $\left(25^{\circ} \mathrm{C}\right)$ for a maximum period of 14 days [13]. It should be noted that SB5 may only be used as indicated in the summary of product characteristics. The objective of this study was to evaluate the stability of SB5, aged to its shelf-life of 36 months, at room temperature $\left(25 \pm 2{ }^{\circ} \mathrm{C}\right)$ and $60 \pm 5 \%$ relative humidity (RH) for a period of 4 weeks. These conditions, which differ from standard accelerated stability studies by using SB5 aged to its shelf-life, represent a worst-case scenario in terms of medication storage. Of interest was whether the physicochemical and biological quality attributes of SB5 were stable for a longer period of time at room temperature $\left(25 \pm 2{ }^{\circ} \mathrm{C}\right)$ than the 2 weeks reported for SB5 currently approved in the European Union.

\section{METHODS}

This article does not contain any studies with human participants or animals performed by any of the authors.

Forty-six syringes ( $0.8 \mathrm{~mL} /$ syringe) for each of three batches were used for testing at each time point. SB5 aged for 36 months at $5 \pm 3{ }^{\circ} \mathrm{C}$ was stored at room temperature $\left(25 \pm 2^{\circ} \mathrm{C}\right)$ and $60 \pm 5 \%$ RH for 4 weeks in light-protected conditions. SB5 stability was assessed at 0,2 , and 4 weeks of storage. The following categories were assessed: visual characteristics (color, clarity, visible particles), $\mathrm{pH}$, chemical analysis (protein concentration), physicochemical analysis [high molecular weight (HMW) impurities, overall purity, low molecular weight (LMW) impurities such as nonglycosylated heavy chain (NGHC), and charge isoforms], subvisible particulates (particulate matter), and biological activity (TNF-alpha binding and neutralization). Table 1 summarizes the techniques used to assess each quality attribute.

\section{RESULTS}

Tables 2, 3, and 4 summarize the stability characteristics of batches at weeks 0,2 , and 4 . Color, clarity, visible particles, $\mathrm{pH}$, protein concentration, and particulate matter were consistent among batches, and all test results met the acceptance criteria at each time point. 
Table 1 Summary of methods used for determining stability of SB5

\begin{tabular}{|c|c|c|c|}
\hline Category & $\begin{array}{l}\text { Product quality } \\
\text { attribute }\end{array}$ & Method & Objective \\
\hline \multirow{3}{*}{$\begin{array}{l}\text { Visual } \\
\text { characteristic }\end{array}$} & Color & Visual inspection & Evaluation of color using brown standard B1-B7 \\
\hline & Clarity & $\begin{array}{r}\text { Turbidity measurement by } \\
\text { HACH Model 2100AN }\end{array}$ & Evaluation of level of clarity of sample \\
\hline & Visible particles & Visual inspection & Determination of number of visible particles \\
\hline $\mathrm{pH}$ & $\mathrm{pH}$ & $\begin{array}{l}\mathrm{pH} \text { measurement by Thermo } \\
\text { Scientific Orion Star A211 }\end{array}$ & Evaluation of $\mathrm{pH}$ \\
\hline $\begin{array}{r}\text { Chemical } \\
\text { analysis }\end{array}$ & $\begin{array}{l}\text { Protein } \\
\text { concentration }\end{array}$ & $\begin{array}{l}\mathrm{A}_{280} \text { measurement by UV-VIS } \\
\text { spectrophotometer }\end{array}$ & Determination of concentration of protein \\
\hline \multirow[t]{4}{*}{$\begin{array}{l}\text { Physicochemical } \\
\text { analysis }\end{array}$} & HMW impurities & SE-HPLC & $\begin{array}{l}\text { Determination of the percentage of HMW } \\
\text { impurities }\end{array}$ \\
\hline & Overall purity & CE-SDS & Determination of total purity \\
\hline & LMW impurities & CE-SDS & $\begin{array}{l}\text { Determination of the presence of LMW } \\
\text { impurities (e.g., NGHC) }\end{array}$ \\
\hline & Charge isoforms & CEX-HPLC, icIEF & $\begin{array}{l}\text { Determination of the change in charge variance, } \\
\text { including acidic, main, and basic variants }\end{array}$ \\
\hline $\begin{array}{l}\text { Subvisible } \\
\text { particulates }\end{array}$ & Particulate matter & $\begin{array}{l}\text { HIAC } 9703+\text { and HRLD- } \\
\quad 400\end{array}$ & $\begin{array}{l}\text { Determination of the number of particles that } \\
\text { are } \geq 25, \geq 10\end{array}$ \\
\hline \multirow[t]{2}{*}{$\begin{array}{l}\text { Biological } \\
\text { activity }\end{array}$} & $\begin{array}{l}\text { TNF-alpha } \\
\text { binding activity }\end{array}$ & FRET & $\begin{array}{l}\text { Determination of the relative binding to the } \\
\text { reference standard }\end{array}$ \\
\hline & $\begin{array}{l}\text { TNF-alpha } \\
\text { neutralization } \\
\text { activity }\end{array}$ & $\begin{array}{l}\text { Luciferase reporter gene system } \\
\text { assay }\end{array}$ & $\begin{array}{l}\text { Determination of the relative potency to the } \\
\text { reference standard }\end{array}$ \\
\hline
\end{tabular}

$A_{280}$ absorbance at $280 \mathrm{~nm}, C E-S D S$ capillary electrophoresis-sodium dodecyl sulfate, $C E X-H P L C$ cation exchange highperformance liquid chromatography, FRET fluorescence resonance energy transfer, $H M W$ high molecular weight, icIEF imaged capillary isoelectric focusing, $L M W$ low molecular weight, $N G H C$ non-glycosylated heavy chain, SE-HPLC sizeexclusion high-performance liquid chromatography, $T N F$-alpha tumor necrosis factor

Figure 1 shows the percent of HMW species (Fig. 1a), total purity (Fig. 1b), and percent of NGHC (Fig. 1c). Size-exclusion high-performance liquid chromatography (SE-HPLC) analysis showed a negligible increase (up to $0.1 \%$ ) in the percent of HMW species after 4 weeks of storage at $25 \pm 2{ }^{\circ} \mathrm{C}$ and $60 \pm 5 \% \mathrm{RH}$ for each SB5 batch; all values were within the acceptance criteria limits. A non-reducing capillary electrophoresis-sodium dodecyl sulfate (CE-SDS) was employed as an analytical method, which enabled complete resolution and better separation of incomplete antibody fragments and LMW variants compared to SE-HPLC. Total purity as measured by CE-SDS was not changed for any batch, and the level of LMW impurities did not change over the storage period, consistent with SE-HPLC data. There was no significant increase in the percent of NGHC, as measured by reduced CE-SDS, for any batch. Taken together, these results suggest there was no significant change in SB5 molecular weight variants over the 4 -week study period. 
Table 2 Stability of aged SB5 batch 1 at room temperature $\left(25 \pm 2{ }^{\circ} \mathrm{C}\right)$ and $60 \pm 5 \%$ relative humidity

\begin{tabular}{|c|c|c|c|c|}
\hline \multirow[t]{2}{*}{ Category } & \multirow[t]{2}{*}{ Test item } & \multicolumn{3}{|c|}{ Time point/sampling date (week) } \\
\hline & & $\mathbf{0}$ & 2 & 4 \\
\hline \multirow[t]{4}{*}{ General } & Color & B8 $<$ sample $<$ B7 & $\mathrm{B} 9 \leq$ sample $<\mathrm{B} 8$ & B8 $<$ sample $<$ B7 \\
\hline & Clarity, NTU & 18 & 19 & 17 \\
\hline & Visible particles & $\begin{array}{l}\text { Practically free from } \\
\text { particles }\end{array}$ & $\begin{array}{l}\text { Practically free from } \\
\text { particles }\end{array}$ & $\begin{array}{l}\text { Practically free from } \\
\text { particles }\end{array}$ \\
\hline & $\mathrm{pH}$ & 5.3 & 5.3 & 5.2 \\
\hline Quantity & $\begin{array}{l}\text { Protein concentration }\left(\mathrm{A}_{280}\right) \text {, } \\
\mathrm{mg} / \mathrm{mL}\end{array}$ & 50.8 & 50.8 & 51.7 \\
\hline \multirow[t]{3}{*}{ Safety } & \multicolumn{4}{|c|}{ Particulate matter, particles/syringe } \\
\hline & $\geq 25 \mu \mathrm{m}$ & 10 & 19 & 38 \\
\hline & $\geq 10 \mu \mathrm{m}$ & 1312 & 1204 & 1361 \\
\hline
\end{tabular}

The acceptance criteria of particulate matter are "Particle $\geq 10 \mu \mathrm{m}: \leq 6000 /$ syringe" and "Particle $\geq 25 \mu \mathrm{m}: \leq 600$ / syringe” according to Ph. Eur. 2.9.19/<USP 788 $>$

$A_{280}$ absorbance at $280 \mathrm{~nm}, N T U$ nephelometric turbidity unit

Table 3 Stability of aged SB5 batch 2 at room temperature $\left(25 \pm 2{ }^{\circ} \mathrm{C}\right)$ and $60 \pm 5 \%$ relative humidity

\begin{tabular}{|c|c|c|c|c|}
\hline \multirow[t]{2}{*}{ Category } & \multirow[t]{2}{*}{ Test item } & \multicolumn{3}{|c|}{ Time point/sampling date (week) } \\
\hline & & $\mathbf{0}$ & 2 & 4 \\
\hline \multirow[t]{4}{*}{ General } & Color & $\mathrm{B} 7 \leq$ Sample $<$ B 6 & Colorless & B8 $<$ Sample $<$ B7 \\
\hline & Clarity, NTU & 16 & 17 & 18 \\
\hline & Visible particles & $\begin{array}{l}\text { Practically free from } \\
\text { particles }\end{array}$ & $\begin{array}{l}\text { Practically free from } \\
\text { particles }\end{array}$ & $\begin{array}{l}\text { Practically free from } \\
\text { particles }\end{array}$ \\
\hline & $\mathrm{pH}$ & 5.2 & 5.2 & 5.3 \\
\hline Quantity & $\begin{array}{l}\text { Protein concentration }\left(\mathrm{A}_{280}\right) \text {, } \\
\mathrm{mg} / \mathrm{mL} \text { : }\end{array}$ & 50.5 & 49.0 & 50.4 \\
\hline \multirow[t]{3}{*}{ Safety } & \multicolumn{4}{|c|}{ Particulate matter, particles/syringe } \\
\hline & $\geq 25 \mu \mathrm{m}$ & 14 & 23 & 18 \\
\hline & $\geq 10 \mu \mathrm{m}$ & 1364 & 1089 & 1234 \\
\hline
\end{tabular}

The acceptance criteria of particulate matter are "Particle $\geq 10 \mu \mathrm{m}: \leq 6000 /$ syringe" and "Particle $\geq 25 \mu \mathrm{m}: \leq 600 /$ syringe” acccording to Ph. Eur. 2.9.19/<USP 788>

$A_{280}$ absorbance at $280 \mathrm{~nm}, N T U$ nephelometric turbidity unit 
Table 4 Stability of aged SB5 Batch 3 at room temperature $\left(25 \pm 2{ }^{\circ} \mathrm{C}\right)$ and $60 \pm 5 \%$ relative humidity

\begin{tabular}{lllll}
\hline Category & Test item & \multicolumn{2}{l}{ Time point/sampling date (week) } \\
\cline { 3 - 5 } & & $\mathbf{0}$ & $\mathbf{2}$ & $\mathbf{4}$ \\
\hline General & Color & $\mathrm{B} 7 \leq$ sample $<\mathrm{B} 6$ & Colorless & $\mathrm{B} 8<$ sample $<$ B7 \\
& Clarity, NTU & 16 & 17 & 17 \\
& Visible particles & Practically free from & Practically free from & Practically free from \\
& & particles & particles & particles \\
& $\mathrm{pH}$ & 5.2 & 5.2 & 5.3 \\
Quantity & Protein concentration $\left(\mathrm{A}_{280}\right)$, & 51.4 & 49.4 & 50.4 \\
& mg/mL & & & \\
Safety & Particulate matter, particles/syringe & 13 & 15 & 13 \\
& $\geq 25 \mu \mathrm{m}$ & 1401 & 923 & 1084 \\
\hline
\end{tabular}

The acceptance criteria of particulate matter are "Particle $\geq 10 \mu \mathrm{m}: \leq 6000 / /$ syringe" and "Particle $\geq 25 \mu \mathrm{m}: \leq 600 /$ syringe" according to Ph. Eur. 2.9.19/<USP 788>

$A_{280}$ absorbance at $280 \mathrm{~nm}, N T U$ nephelometric turbidity unit

Figure 2 shows relative binding activity by TNF-alpha using fluorescence resonance energy transfer (Fig. 2a) and relative potency by TNFalpha neutralization using an NF- $\mathrm{KB}$ reporter gene system (Fig. 2b). Over the 4-week period, the results of the relative binding assay and relative potency assay did not change significantly for any batch tested, suggesting that biological activity, including binding activity and potency, were maintained for 4 weeks. The results met the acceptance criteria for all batches.

Figure 3 shows the percent acidic charge (Fig. 3a, b), main charge (Fig. 3c, d), and basic charge (Fig. 3e, f). The percent acidic, main, and basic profile of SB5, as measured by cation exchange high-performance liquid chromatography (CEX-HPLC) and imaged capillary isoelectric focusing (icIEF), was similarly maintained for each batch over time.

\section{DISCUSSION}

The stability of 36-months-aged SB5 was evaluated at 0,2 , and 4 weeks of storage at room temperature $\left(25 \pm 2{ }^{\circ} \mathrm{C}\right)$ and $60 \pm 5 \% \quad \mathrm{RH}$.
Three batches of SB5 were independently tested for solution appearance, $\mathrm{pH}$, protein concentration, purity, particulate size, biological activity, and charge variance. The results of this study demonstrate that SB5, aged to its shelflife, is physicochemically and biologically stable for up to 4 weeks at room temperature $\left(25 \pm 2{ }^{\circ} \mathrm{C}\right)$ and $60 \pm 5 \% \mathrm{RH}$, which may indicate longer utility and, in turn, may potentially offer improved convenience in storage.

The color, clarity, and presence of visible particulates of SB5 did not change over time and met acceptance criteria at each time point tested, indicating the absence of large aggregate formation and suggesting that the storage conditions had little to no impact on the quality attributes of SB5. Variations in $\mathrm{pH}$ can be responsible for the degradation of monoclonal antibodies [14]; however, the pH of SB5 also remained stable throughout the 4-week storage period. The lack of significant change in charge variance of SB5 over time was verified using icIEF and CEX-HPLC, which indicated an absence of change to the initial structure. HMW impurities, which are one of the most sensitive indicators of stability, did not increase 
(a)

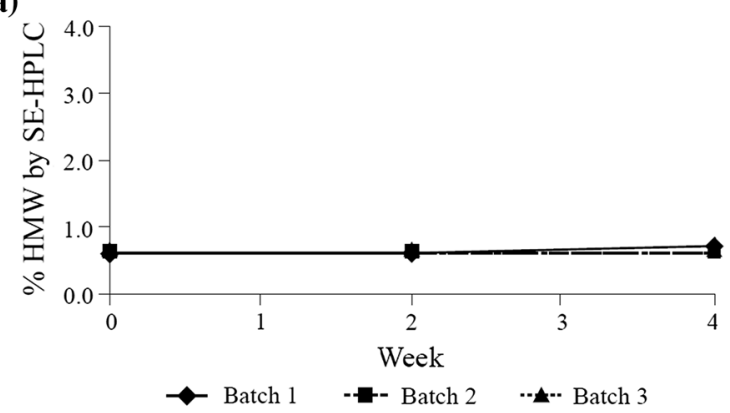

(b)

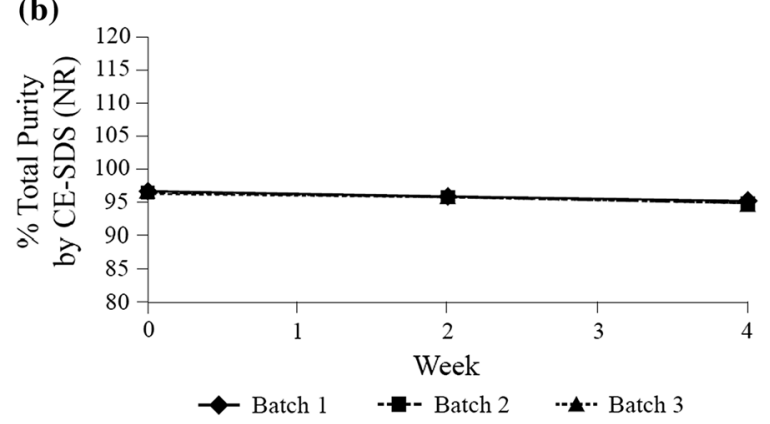

(c)

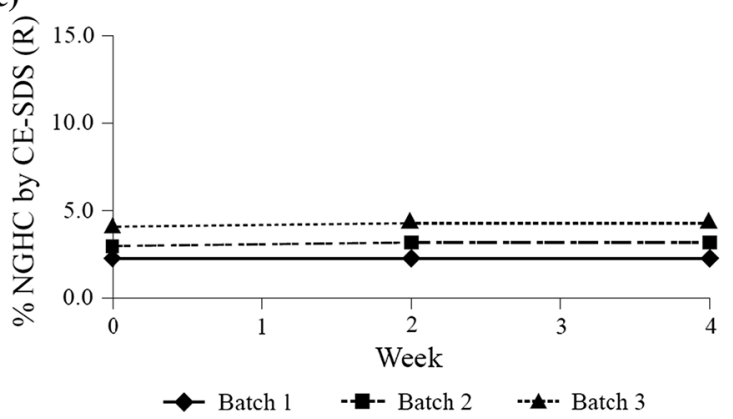

Fig. 1 Stability trends of aged SB5 (batches 1,2, and 3) at room temperature $\left(25 \pm 2{ }^{\circ} \mathrm{C}\right)$ and $60 \pm 5 \% \mathrm{RH}$. a Percent of HMW species as measured by SE-HPLC. b Percent total purity as measured by CRE-SDS (NR). c Percent of NGHC as measured by reduced CE-SDS. CE-SDS capillary electrophoresis-sodium dodecyl sulfate, $H M W$ high molecular weight, $N R$ non-reduced, $R H$ relative humidity, $S E-H P L C$ size-exclusion high-performance liquid chromatography

throughout the 4-week storage period, indicating that SB5 stability is maintained for up to 4 weeks. The total purity of SB5 remained $\geq 95.0 \%$, and the degree of non-glycosylation of antibody heavy chains remained low (no higher than $4.3 \%$ ) for up to 4 weeks, demonstrating that there was no degradation of the monoclonal antibodies.
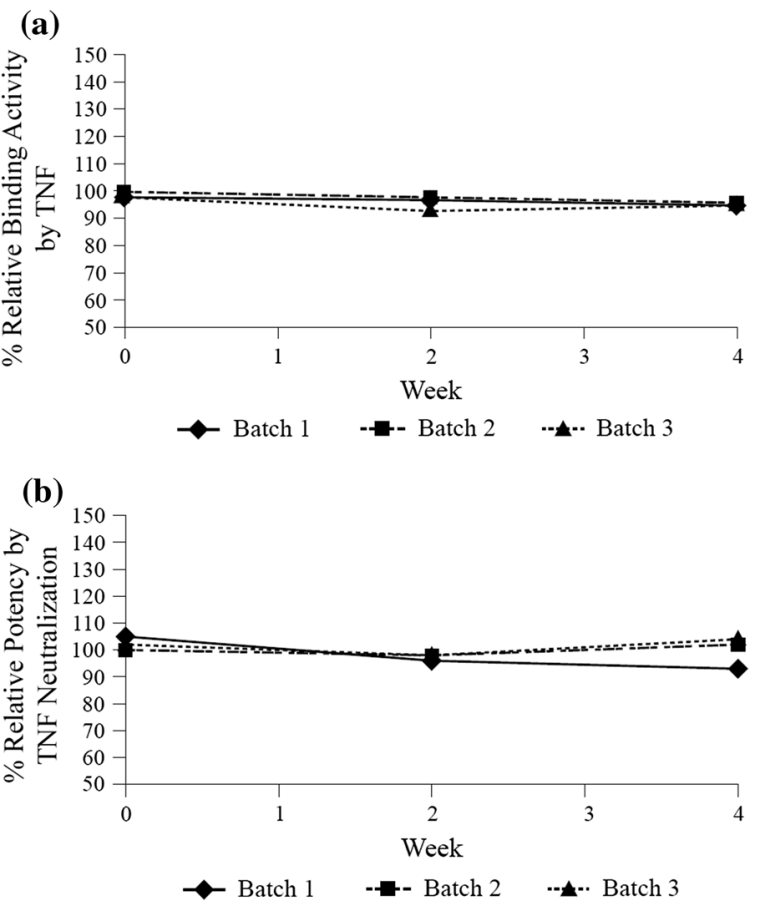

Fig. 2 Stability trends of aged SB5 (batches 1, 2, and 3) at room temperature $\left(25 \pm 2{ }^{\circ} \mathrm{C}\right)$ and $60 \pm 5 \% \mathrm{RH}$. a Percent relative binding activity by TNF-alpha. b Percent relative potency by TNF-alpha neutralization. $R H$ relative humidity, $T N F$ tumor necrosis factor

The stability of SB5 biological activity over the 4-week period was not changed, as measured by competitive inhibition binding and TNF-alpha neutralization assays. As biological activity is a parameter indicative of efficacy, this maintenance of biological activity may suggest lasting efficacy up to 4 weeks of storage at $25 \pm 2{ }^{\circ} \mathrm{C}$ and $60 \pm 5 \% \mathrm{RH}$.

Although this study adopted a broad type of analytical tools to evaluate a stability of aged SB5 under room temperature storage for 4 weeks, microbial testing [e.g., endotoxins, sterility, container closure integrity (CCI)] was not conducted in this study as it had previously been determined that CCI was maintained throughout more stringent conditions in previously performed temperature cycling studies (unpublished observations). In these temperature cycling studies, SB5 was exposed to multiple conditions $\left(-5^{\circ} \mathrm{C}\right.$ and $25^{\circ} \mathrm{C}$ at $60 \% \mathrm{RH}$ and $40{ }^{\circ} \mathrm{C}$ at $\left.75 \% \mathrm{RH}\right)$, and the results met acceptance criteria at each condition. This indicated 

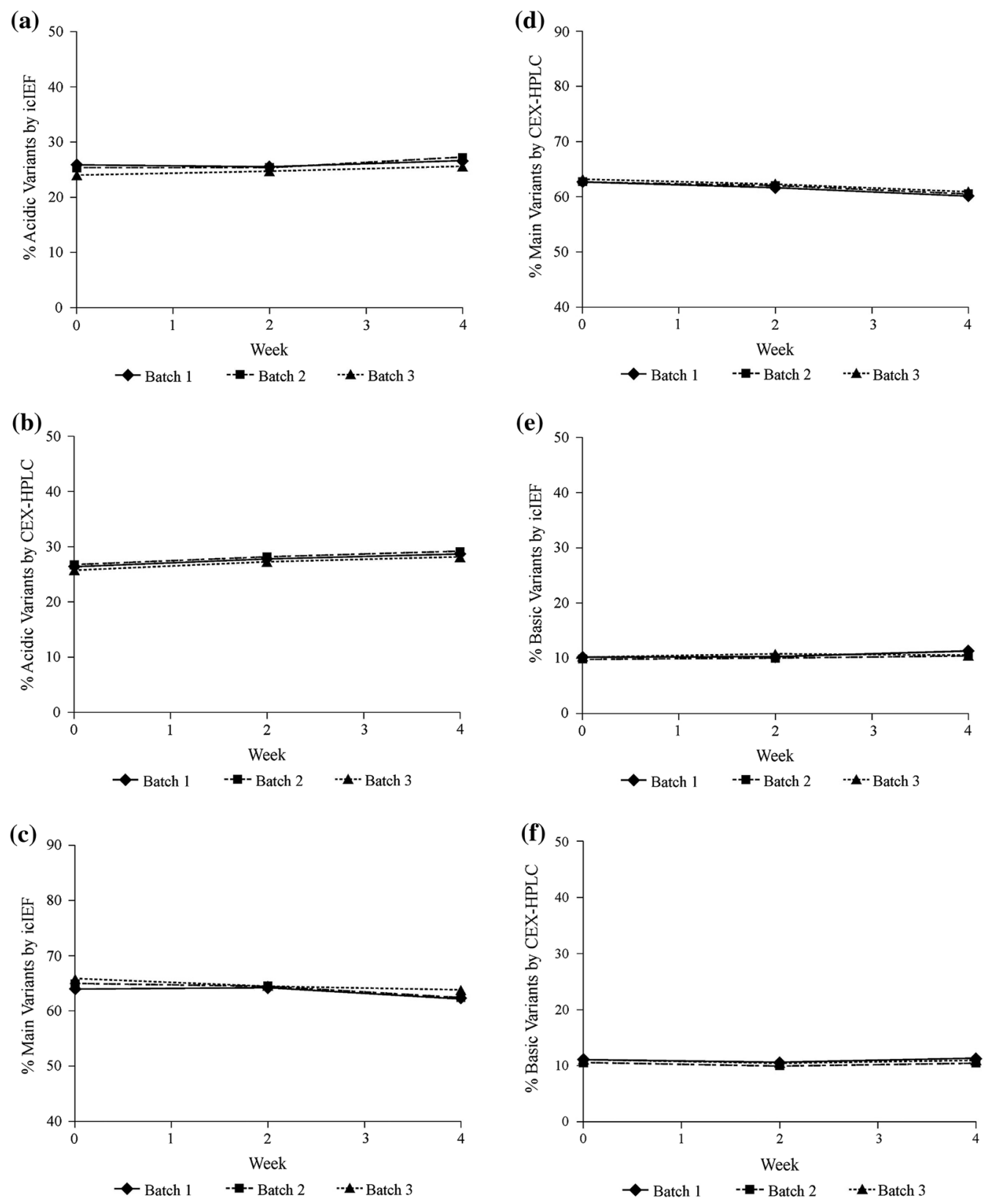

Fig. 3 Stability trends of aged SB5 (batches 1, 2, and 3) at room temperature $\left(25 \pm 2{ }^{\circ} \mathrm{C}\right)$ and $60 \pm 5 \% \mathrm{RH}$. Percent acidic variants as measured by $\mathbf{a}$ icIEF and $\mathbf{b}$ CEXHPLC. Percent main variants as measured by $\mathbf{c}$ icIEF and d CEX-HPLC. Percent basic variants as measured by

that the CCI of the microbial barrier would also be maintained under the more moderate conditions used in the present study, which would prevent contamination from other organisms and endotoxins.

e icIEF and f CEX-HPLC. CEX-HPLC cation-exchange high-performance liquid chromatography, icIEF imaged capillary isoelectric focusing, $R H$ relative humidity

Clinical efficacy was also not directly assessed through in vivo testing as part of this study. However, it was confirmed that the stability of SB5 biological activity, which is a parameter indicative of efficacy over the 4 -week period, 
was not changed, as measured by competitive inhibition binding and TNF-alpha neutralization assays. In addition, with consideration of no change in the results for more sensitive phisyco-chemical stability indicating methods, such as SEC, non-reduced CE-SDS, and icIEF, we can conclude that there is no risk of leading to a reduced clinical efficacy.

Biologics are inherently heterogeneous and may vary from batch to batch [4]. Thus, it is important to ensure that each batch of biologic is highly similar. The results from our study demonstrate that SB5 displayed quality attributes that were similar between batches. Additionally, this similarity was maintained over the 4-week storage period both within and between batches. Although statistical analyses were not performed, the results from each batch and attribute met acceptance criteria, and no trends towards increases or decreases in attributes were observed over the storage period, suggesting that similarity was maintained within this timeframe.

The limitation of this study is not performing microbial testing and in vivo testing to confirm clinical efficacy as part of this study.

Our findings are consistent with a previous study examining the stability of 24-monthsaged SB5 (unpublished observations). As biological therapeutics are susceptible to rapid degradation through a variety of biochemical mechanisms [15], long-term and room-temperature stability are important.

\section{CONCLUSIONS}

The stability of SB5, aged to its shelf-life representing a worst-case scenario in terms of medication storage, was evaluated through physicochemical and biological methods.

The ADA biosimilar SB5 remained stable and biologically active for 4 weeks at room temperature $\left(25 \pm 2{ }^{\circ} \mathrm{C}\right)$ and $60 \pm 5 \% \mathrm{RH}$, with little to no within- or between-batch variability. This stability profile is 2 weeks longer than that of SB5 currently approved in the European Union [13].

\section{ACKNOWLEDGEMENTS}

Funding. Sponsorship for this study, article processing charges and the open access fee were funded by Samsung Bioepis Co., Ltd. All authors had full access to all of the data in this study and take complete responsibility for the integrity of the data and accuracy of the data analysis.

Medical Writing Assistance. Medical writing assistance was provided by Eric Comeau, $\mathrm{PhD}$, at C4 MedSolutions, LLC (Yardley, PA, USA), a CHC Group company, and was funded by Samsung Bioepis Co., Ltd.

Authorship. All named authors meet the International Committee of Medical Journal Editors (ICMJE) criteria for authorship for this article, take responsibility for the integrity of the work as a whole, and have given their approval for this version to be published.

Disclosures. Dongkuk Park is an employee of Samsung Bioepis Co., Ltd. Jihoon Yun is an employee of Samsung Bioepis Co., Ltd. Su-Jeong Hwang is an employee of Samsung Bioepis Co., Ltd. Su Jin Park is an employee of Samsung Bioepis Co., Ltd.

Compliance with Ethics Guidelines. This article does not contain any studies with human participants or animals performed by any of the authors.

Data Availability. The datasets generated during and/or analyzed during the current study are not publicly available due the datasets are private property but are available from the corresponding author on reasonable request.

Open Access. This article is distributed under the terms of the Creative Commons Attribution-NonCommercial 4.0 International License (http://creativecommons.org/licenses/ by-nc/4.0/), which permits any noncommercial use, distribution, and reproduction in any medium, provided you give appropriate credit to the original author(s) and the source, provide 
a link to the Creative Commons license, and indicate if changes were made.

\section{REFERENCES}

1. Humira ${ }^{\circledR}$ (adalimumab). Summary of product characteristics. Ludwigshafen: AbbVie Deutschland GmbH \& Co. KG; 2018.

2. Tansey MG, Szymkowski DE. The TNF superfamily in 2009: new pathways, new indications, and new drugs. Drug Discov Today. 2009;14:1082-8.

3. Hu S, Liang $\mathrm{S}$, Guo $\mathrm{H}$, et al. Comparison of the inhibition mechanisms of adalimumab and infliximab in treating tumor necrosis factor alpha-associated diseases from a molecular view. J Biol Chem. 2013;288:27059-67.

4. Dorner T, Strand V, Castaneda-Hernandez G, et al. The role of biosimilars in the treatment of rheumatic diseases. Ann Rheum Dis. 2013;72:322-8.

5. Shin D, Kim Y, Kim HS, Fuhr R, Kornicke T. A phase I pharmacokinetic study comparing SB5, an adalimumab biosimilar, and adalimumab reference product $\left(\right.$ HUMIRA $^{\circledR}$ ) in healthy subjects. Ann Rheum Dis. 2015;74:459.

6. Lee N, Lee JJ, Yang $\mathrm{H}$, et al. Evaluation of similar quality attribute characteristics in SB5 and reference product of adalimumab. MAbs. 2018. https://doi. org/10.1080/19420862.2018.1530920.
7. Shin D, Lee Y, Kim H, Kornicke T, Fuhr R. A randomized phase I comparative pharmacokinetic study comparing SB5 with reference adalimumab in healthy volunteers. J Clin Pharm Ther. 2017;42:672-8.

8. Weinblatt ME, Baranauskaite A, Niebrzydowski J, et al. Phase III randomized study of SB5, an adalimumab biosimilar, versus reference adalimumab in patients with moderate-to-severe rheumatoid arthritis. Arthritis Rheumatol. 2018;70:40-8.

9. Amgevita ${ }^{\mathrm{TM}}$ (adalimumab). Summary of product characteristics. Breda: Amgen Europe B.V; 2018.

10. Hyrimoz ${ }^{\circledR}$ (adalimumab). Summary of product characteristics. Kundl: Sandoz GmbH; 2018.

11. Cyltezo ${ }^{\circledR}$ (adalimumab). Summary of product characteristics. Ingelheim am Rhein: Boehringer Ingelheim International GmbH; 2018.

12. Hulio ${ }^{\circledR}$ (adalimumab). Summary of product characteristics. Saint-Priest: Mylan S.A.S; 2018.

13. Imraldi ${ }^{\circledR}$ (adalimumab). Summary of product characteristics. 2616 LR Delft: Samsung Bioepis NL B.V.; 2018.

14. Chi EY, Krishnan S, Randolph TW, Carpenter JF. Physical stability of proteins in aqueous solution: mechanism and driving forces in nonnative protein aggregation. Pharm Res. 2003;20:1325-36.

15. Manning MC, Chou DK, Murphy BM, Payne RW, Katayama DS. Stability of protein pharmaceuticals: an update. Pharm Res. 2010;27:544-75. 